\title{
MORPHOLOGICAL FEATURES OF CELLULAR INFILTRATION IN THE MUCOSA OF LARGE INTESTINE IN ULCERATIVE COLITIS AND IRRITABLE BOWEL SYNDROME
}

10.36740/WLek202101111

\author{
Olena 0. Dyadyk, Pavlo P. Snisarevskyi, Tetiana P. Snisarevska \\ SHUPYK NATIONAL MEDICAL ACADEMY OF POSTGRADUATE EDUCATION, KYIV, UKRAINE
}

\begin{abstract}
The aim is to improve morphological diagnostics, including differential, of UC and IBS, identifying morphological features of cellular infiltration in the mucous membrane of the large intestine.

Material and methods: Autopsy and biopsy material - fragments of the mucous membrane of the large intestine was used in this study. All the material was divided into 5 groups. Group 1 included autopsy material from 6 cases, in which no general pathological processes in the gastrointestinal tract were detected during autopsy and microscopic examination. Group 2 included biopsy material from 34 patients with diagnosed UC of the $1^{\text {st }}$ activity degree. Group 3 included the biopsy material of 27 patients with UC of the $2^{\text {nd }}$ degree of activity. Group 4 included biopsy material from 19 patients, diagnosed with UC of the $3^{\text {rd }}$ degree of activity. Group 5 included biopsy material from 82 patients with clinically diagnosed IBS. Histological, morphometrical, immunohistochemical and statistical methods of investigation were used.

Results: The mucous membrane of the large intestine in patients with ulcerative colitis of varying degrees of activity, compared with the physiological norm, has pronounced infiltration by plasma cells, T-lymphocytes, B-lymphocytes, macrophages, mast cells, eosinophilic and neutrophilic leukocytes in the superficial parts of the epithelium, crypts, lamina propria. There is also an increase in the number and size of lymphoid follicles in the lamina propria. Predominant cellular elements in the infiltrate are plasma cells, T-lymphocytes, eosinophilic and neutrophilic leukocytes.

The growth of ulcerative colitis activity leads to an increase the inflammatory cell infiltration in the mucous membrane of the colon, as evidenced an increase the density of cellular infiltrate; the severity of inflammatory changes in crypts and an increase in the number of crypt abscesses; a decrease the number of cases with focal infiltration in the lamina propria and an increase the number of cases with diffuse infiltration; the spread of inflammatory cell infiltration from the superficial parts of the lamina propria to its deep parts with the subsequent involvement of its entire thickness; an increase the central trends of the indexes of the severity of all cellular infiltration, infiltration by plasma cells, T-lymphocytes, macrophages, neutrophilic leukocytes.

The mucous membrane of the large intestine in patients with irritable bowel syndrome has moderately pronounced cellular infiltration in the superficial epithelium and lamina propria, in comparison with the physiological norm. The number and size of lymphoid follicles increase. Inflammatory cell infiltration often spreads to the upper one third or two thirds of the thickness of the lamina propria, characterized by the presence of plasma cells, T-lymphocytes, B-lymphocytes, macrophages, mast cells, eosinophilic and neutrophilic leukocytes. In this case, plasma cells, T-lymphocytes, mast cells and macrophages dominate. The indexes of the severity of all cellular infiltration, as well as infiltration by plasma cells, T-lymphocytes, B-lymphocytes, macrophages, mast cells, eosinophilic and neutrophilic leukocytes, increases in the mucous membrane of the large intestine in irritable bowel syndrome in comparison with the norm.

In the mucous membrane of the large intestine in irritable bowel syndrome compared with ulcerative colitis of varying degrees of activity inflammatory cell infiltration is less pronounced. It often extends to one third or two thirds of the thickness of the lamina propria. There are fewer lymphoid follicles, cryptitis and crypt abscesses are not determined. The indexes of the severity of all cellular infiltration, as well as infiltration by plasma cells, T-lymphocytes, eosinophilic and neutrophilic leukocytes are lower.

Conclusions: The revealed features of cellular infiltration in the mucous membrane of the large intestine make it possible to improve morphological diagnostics, including differential, of ulcerative colitis of varying degrees of activity and irritable bowel syndrome.
\end{abstract}

KEY WORDS: ulcerative colitis, irritable bowel syndrome, large intestine mucosa, cellular infiltration, morphology

\section{INTRODUCTION}

Ulcerative colitis (UC), being one of the most serious and unsolved problems of modern medicine, is characterized by inflammation of the colon mucosa, involving rectum, and possible retrograde spread of the inflammatory process to the proximal part of the ileum [1].

The UC prevalence in the world is 50-230 cases per 100 thousand population, the annual increase in patients is $5-20$ cases per 100 thousand population. The highest incidence is in North America, Northern Europe and Australia, less often this pathology is recorded in Asia, South America and Japan. Among the white population, this pathology occurs 3-5 times more often than among African Americans, among Jews - 3.5 times more often than among non-Jewish people [2].

To date, etiology and pathogenesis of UC are not sufficiently studied. UC is characterized by a long course and 
development of formidable complications. It leads to a high level of disability among young and mature people of working age, causing certain diagnostic difficulties for doctors, including during conducting differential diagnostics with IBS. The latter, according to the IV revision of the Rome criteria for functional disorders of the gastrointestinal tract, is determined as a functional disorder of the intestine. It is characterized by recurring abdominal pain at least once a week for the last 3 months, associated with the act of defecation and combined with changes in stool frequency and consistency of feces, with a total duration of complaints of at least 6 months [3].

Actualization of IBS diagnosing is determined by a decrease in the quality of patients' life, serious economic losses and epidemiological characteristics. IBS prevalence in the world is $11.2 \%$. It is more common in women and, which is important, in young people [4].

Difficulties in the differential diagnosis of UC and IBS, as shown by numerous studies, are due to common clinical manifestations, genetic changes, disorders of the brain-intestinal axis, as well as disorders of the intestinal microbiota, etc. [5].

Thus, the question of finding the most significant criteria for differential diagnosis of UC and IBS remains relevant. An important role in the search for such diagnostic criteria belongs to colonoscopy with taking biopsy and its subsequent study, using various morphological research methods. Biopsy is considered a «gold» standard in the intravital diagnosis of intestinal pathology [6].

\section{THE AIM}

The aim is to improve morphological diagnostics, including differential, of UC and IBS, identifying morphological features of cellular infiltration in the mucous membrane of the large intestine.

\section{MATERIAL AND METHODS}

Autopsy and biopsy material - fragments of the mucous membrane of the large intestine was used in this study. All the material was divided into 5 groups. Group 1 included autopsy material from 6 cases, in which no general pathological processes in the gastrointestinal tract were detected during autopsy and microscopic examination. Group 2 included biopsy material from 34 patients with diagnosed UC of the $1^{\text {st }}$ activity degree. Group 3 included the biopsy material of 27 patients with UC of the $2^{\text {nd }}$ degree of activity. Group 4 included biopsy material from 19 patients, diagnosed with UC of the $3^{\text {rd }}$ degree of activity. Group 5 included biopsy material from 82 patients with clinically diagnosed IBS. In patients in groups $2-4$, UC was diagnosed based on clinical data, colonoscopy results and biopsy studies.

The resulting material was fixed in a $10 \%$ solution of neutral formalin (ph 7.4) for 24-48 hours, carried out according to the generally accepted technique and embedded in paraffin. From paraffin blocks on a rotational microtome
HM 325 (Thermo Fisher Scientific, USA), serial sections with a thickness of $2 \mu \mathrm{m}$ were made, stained with hematoxylin and eosin.

Immunohistochemical study was performed using rabbit monoclonal antibodies (MCA) to CD3 (clone SP7) (marker of T-lymphocytes), murine MCA to CD20 Ab-1 (clone L26) (marker of B-lymphocytes), murine MCA to CD138 Ab-2 (clone MI15) (marker of plasma cells), murine MCA to CD68 Ab-3 (clone KP1) (marker of macrophages), rabbit polyclonal antibodies (PCA) to CD117/c-Kit/SCF-Receptor (marker of mast cells). Ultra Vision Quanto HRP detection system was used in visualization. MCA, PCA, and imaging systems were manufactured by Thermo Fisher Scientific (USA).

Microscopic examination and photoarchiving were performed using light optical microscope Axio Imager. A2 (Carl Zeiss, Germany) with data processing system with magnified lenses $\times 5, \times 10, \times 20, \times 40$, binocular nozzle 1.5 and glasses 10 with ERc 5s camera, light optical microscope Primo Star (Carl Zeiss, Germany) with AxioCam 105 camera.

In each case, with a $\times 400$ microscope magnification in 6 fields of view, the severity of the cellular infiltration (\%) was assessed, using an adapted visual-analog scale [7].

The obtained digital data were processed, using the program Statistica 10.0. Central trends in the groups were compared on averages, using the nonparametric Mann-Whitney U test. Differences were considered significant at $\mathrm{p}<0.05$, taking into account the Bonferroni correction [8].

\section{RESULTS AND DISCUSSION}

During the survey microscopy in group 1 there were a few, diffusely located cellular elements in the mucous membrane of the colon between the epithelial cells, in the lamina propria, mainly in its superficial parts. In some fields of view, cellular infiltration was not found, there were single lymphoid follicles. In this group the index of the severity of all cellular infiltration was $(2.31 \pm 0.14) \%$ (fig. 1 ).

During further analysis of hematoxylin and eosin stained microspecimens and the results of the immunohistochemical study it was noted that cellular infiltration in group 1 was represented by CD $3^{+}$-cells, CD $138^{+}$-cells, CD $20^{+}$-cells, CD $68^{+}$-cells, CD $117^{+}$-cells, as well as eosinophilic and neutrophilic leukocytes. In this group, given the value of the index of the severity of cellular infiltration (table I), the $1^{\text {st }}$ rank place was taken by T-lymphocytes, the $2^{\text {nd }}$ place - by plasma cells, mast cells, macrophages, the $3^{\text {rd }}$ place - by eosinophilic and neutrophilic leukocytes, B-lymphocytes. Thus, T-lymphocytes, plasma cells, mast cells and macrophages dominated in the cell infiltrate, identified in group 1 .

Infiltration of immune cells, lymphoid follicles in the mucous membrane of the colon in group 1 are a variant of the norm, which agrees with the data of other scientists. It is known that the density and distribution of chronic inflammatory cells varies with anatomical site. Cellularity 


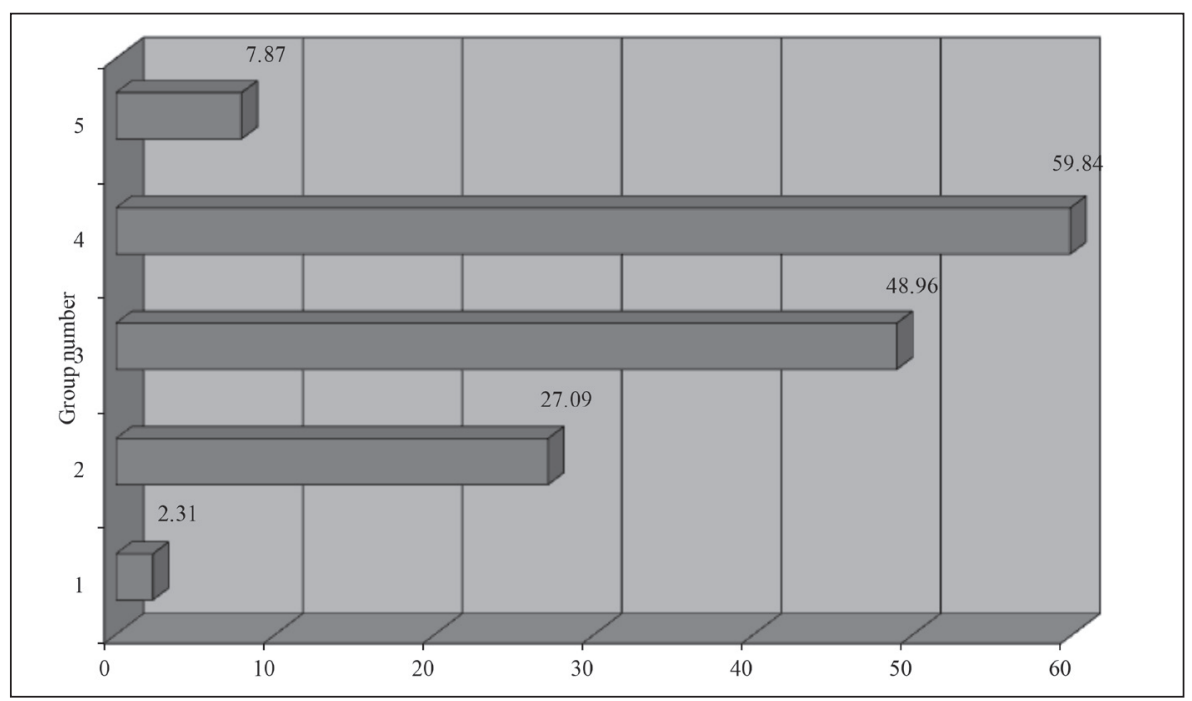

Fig. 1. Central trends of the indexes of the severity of all cellular infiltration (\%) in groups $1-5$.

Table I. Central trends of the indexes of the severity of infiltration by various cells (\%) in groups 1-5.

\begin{tabular}{|c|c|c|c|c|c|}
\hline \multirow{2}{*}{ Cells name } & \multicolumn{5}{|c|}{ Group number } \\
\hline & 1 & 2 & 3 & 4 & 5 \\
\hline $\begin{array}{c}\text { Plasma cells } \\
\text { (CD 138) }\end{array}$ & $3.69 \pm 0.12$ & $\begin{array}{c}30.03 \pm 0.96 \\
1,3,4,5\end{array}$ & $\begin{array}{c}53.56 \pm 1.56 \\
1,2,4,5\end{array}$ & $\begin{array}{c}63.63 \pm 1.92 \\
1,2,3,5\end{array}$ & $\begin{array}{c}14.78 \pm 0.38 \\
1,2,3,4\end{array}$ \\
\hline T-lymphocytes (CD 3) & $5.14 \pm 0.11$ & $\begin{array}{c}9.88 \pm 0.36 \\
1,3,4,5\end{array}$ & $\begin{array}{c}16.26 \pm 0.63 \\
1,2,4,5\end{array}$ & $\begin{array}{c}20.53 \pm 1.00 \\
1,2,3,5\end{array}$ & $\begin{array}{c}7.78 \pm 0.29 \\
1,2,3,4\end{array}$ \\
\hline B-lymphocytes (CD 20) & $0.47 \pm 0.07$ & $\begin{array}{c}1.91 \pm 0.17 \\
1,4\end{array}$ & $\begin{array}{c}2.41 \pm 0.21 \\
1\end{array}$ & $\begin{array}{c}3.79 \pm 0.21 \\
1,2,5\end{array}$ & $\begin{array}{c}1.52 \pm 0.09 \\
1,4\end{array}$ \\
\hline Macrophages (CD 68) & $1.48 \pm 0.17$ & $\begin{array}{c}3.97 \pm 0.14 \\
1,3,4\end{array}$ & $\begin{array}{c}5.93 \pm 0.34 \\
1,2,4\end{array}$ & $\begin{array}{c}8.89 \pm 0.33 \\
1,2,3,5\end{array}$ & $\begin{array}{c}4.48 \pm 0.17 \\
1,4\end{array}$ \\
\hline $\begin{array}{l}\text { Mast cells } \\
(C D 117)\end{array}$ & $2.74 \pm 0.15$ & $\begin{array}{c}5.21 \pm 0.19 \\
1,4\end{array}$ & $\begin{array}{c}6.04 \pm 0.18 \\
1,4\end{array}$ & $\begin{array}{c}8.11 \pm 0.21 \\
1,2,3,5\end{array}$ & $\begin{array}{c}6.99 \pm 0.16 \\
1,4\end{array}$ \\
\hline Eosinophilic leukocytes & $0.59 \pm 0.05$ & $\begin{array}{c}5.68 \pm 0.22 \\
1,4,5\end{array}$ & $\begin{array}{c}6.78 \pm 0.27 \\
1,5\end{array}$ & $\begin{array}{c}7.32 \pm 0.31 \\
1,2,5\end{array}$ & $\begin{array}{c}3.70 \pm 0.10 \\
1,2,3,4\end{array}$ \\
\hline Neutrophilic leukocytes & $0.24 \pm 0.04$ & $\begin{array}{c}5.65 \pm 0.21 \\
1,3,4,5\end{array}$ & $\begin{array}{c}12.30 \pm 0.69 \\
1,2,4,5\end{array}$ & $\begin{array}{c}24.95 \pm 1.15 \\
1,2,3,5\end{array}$ & $\begin{array}{c}1.09 \pm 0.08 \\
1,2,3,4\end{array}$ \\
\hline
\end{tabular}

1 - differences are significant compared to the index of group 1,

${ }^{2}$ - differences are significant compared to the index of group 2,

3 - differences are significant compared to the index of group 3,

${ }^{4}$ - differences are significant compared to the index of group 4,

${ }^{5}$ - differences are significant compared to the index of group 5.

is highest in the caecum/ascending colon and may be low in the rectum $[9,10]$.

The immune system of the gastrointestinal tract, as is known, is located in the mucous membrane and is in close contact with a huge flow of microbial and allergenic material, coming from the intestinal lumen. It serves as the first barrier on its way [11]. A similar infiltration by immune cells is also found in the mucous membrane of the respiratory system, urinary system, etc. [12].

In patients with UC of various degrees of activity (groups $2-4$ ), compared with group 1 , in the mucous membrane of the colon the number and size of lymphoid follicles increased, cell infiltration was more pronounced and increased from group 2 to group 4, as evidenced by survey microscopy (fig. 2,3), analysis of the indexes of the severity of cell infiltration, an immunohistochemical study.

Observational microscopy in groups 2-4 revealed in flammatory cell infiltration in the superficial epithelium, crypt lumen, which indicated cryptitis development and crypt abscesses formation. Presence of cryptitis and crypt abscesses is a characteristic microscopic sign of active UC, which we noted in our previous studies and the works of other scientists $[9,13]$. It was determined that with an increase in the degree of UC activity, inflammatory changes in crypts increased and the number of crypt abscesses increased.

In groups 2-4, inflammatory cell infiltration was also found in the lamina propria of the colon mucosa, where it was irregular, focal, or diffuse, when cellular infiltrates formed continuous fields. In group 2, focal and diffuse 


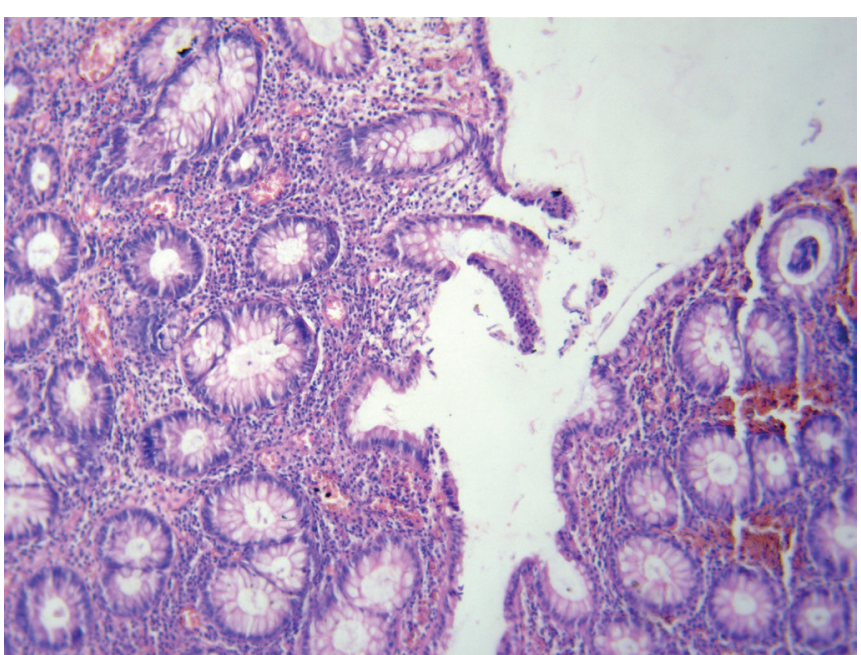

Fig. 2. The mucous membrane of the large intestine of a patient with UC of group 2. Stained with hematoxylin and eosin, $\times 100$.

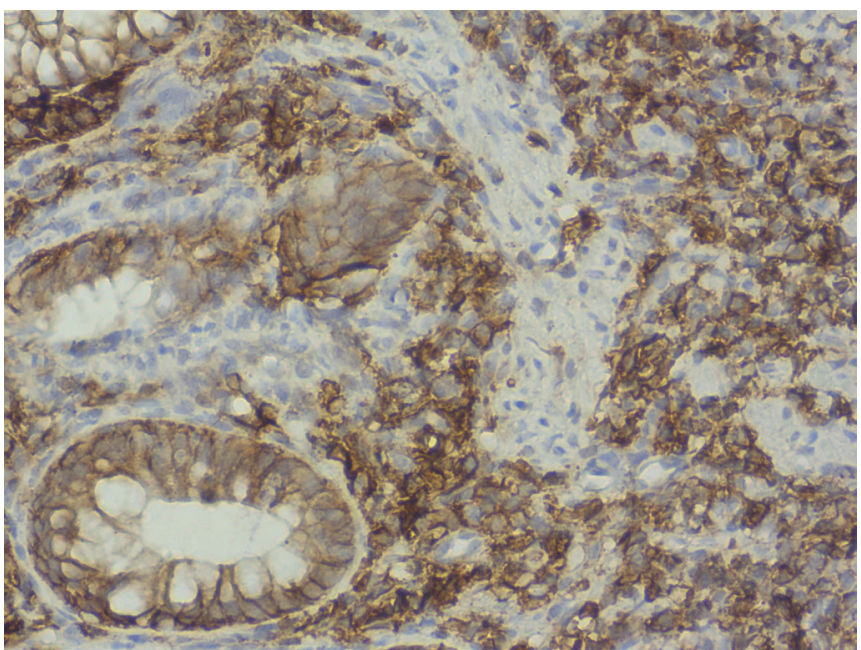

Fig. 4. CD 138+-cells in the mucous membrane of the colon of a patient with UC of group 4. Immunohistochemical reaction with MCA to CD 138 $\mathrm{Ab}-2, \times 400$.

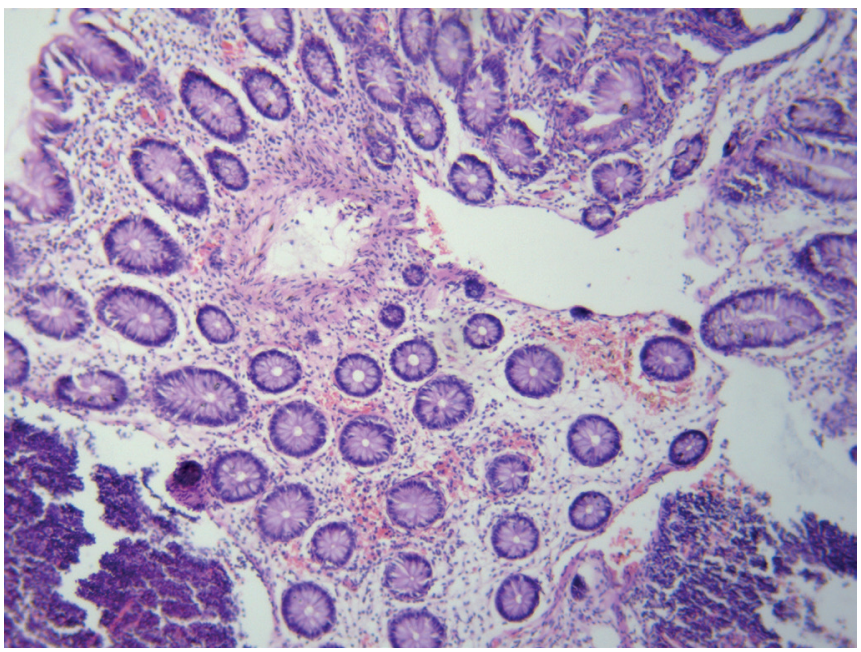

Fig. 6. The mucous membrane of the large intestine of a patient with IBS of group 5. Stained with hematoxylin and eosin, $\times 100$.

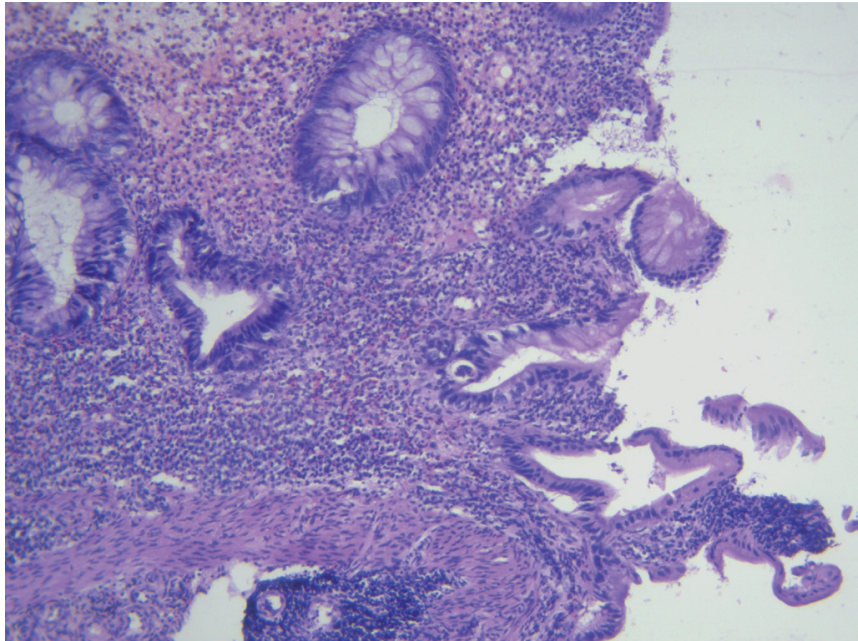

Fig. 3. The mucous membrane of the large intestine of a patient with UC of group 4. Stained with hematoxylin and eosin, $\times 100$.

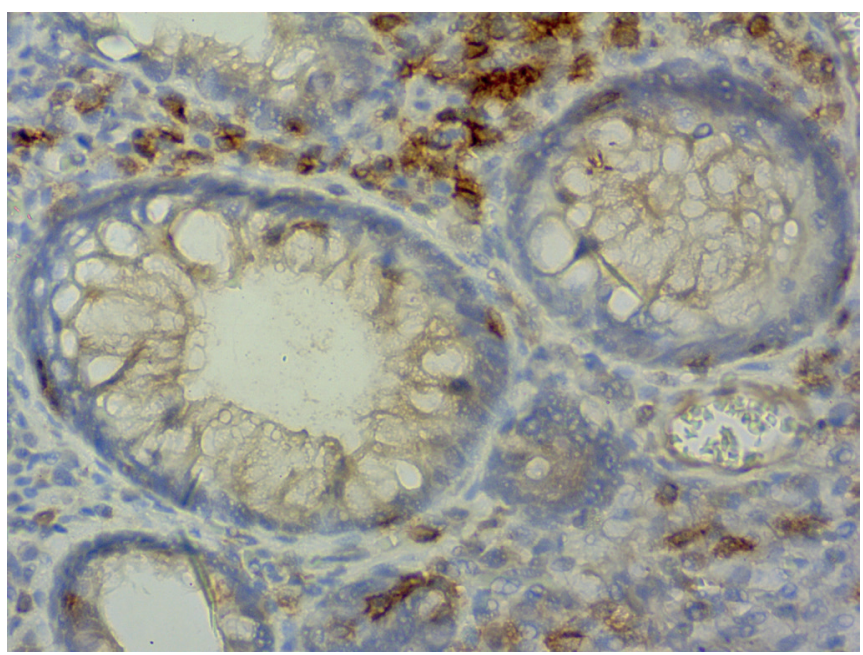

Fig. 5. $C D 3^{+}$-cells in the mucous membrane of the colon of a patient with UC of group 2. Immunohistochemical reaction with MCA to CD $3, \times 100$.

cellular infiltration was detected in $25(73.5 \%)$ and 9 (26.5\%) cases, respectively. In group 3 in 16 (59.3\%) cases focal infiltration was noted, and in 11 (40.7\%) - diffuse. In group 4, inflammatory cell infiltration was focal in 5 cases (26.3\%) and diffuse in $14(73.7 \%)$. Thus, with an increase in UC activity, cell infiltrate density increased, the number of cases with focal infiltration in the lamina propria of the colon mucosa decreased and the number of cases with diffuse infiltration increased.

Under survey microscopy in groups 2-4 in the lamina propria of the colon mucosa, inflammatory cell infiltration was determined in its upper third, occupied two thirds, or spread to its entire thickness. In 2 group, inflammatory cell infiltration in the lamina propria of the mucous membrane in 2 cases $(5.9 \%)$ was located in its upper third, and in 23 (67.6\%) and $9(26.5 \%)$ cases it spread to its two-thirds of the thickness and all its thickness. In group 3, inflammatory infiltration in the lamina propria of the mucous membrane 
was located in 12 cases (44.4\%) in its two-thirds of the thickness, and in 15 cases (55.6\%) in its entire thickness. In group 4, cellular infiltration in the lamina propria was located in its two-thirds and its entire thickness, respectively, in $6(31.6 \%)$ and $13(68.4 \%)$ cases. Thus, with an increase in UC activity, inflammatory cell infiltration spread from the superficial parts of the lamina propria to its deep parts, with the subsequent involvement of its entire thickness.

The index of the severity of all cellular infiltration in the lamina propria of the colon mucosa in groups 2-4 acquired a significantly $(p<0.05)$ higher value than that of group 1 and increased $(\mathrm{p}<0.05)$ from group 2 to group 4 (fig. 1).

In patients of groups 2-4, inflammatory cell infiltration in the mucous membrane of the colon was represented, as in group 1, by plasma cells, T-lymphocytes, B-lymphocytes, macrophages, mast cells, eosinophilic and neutrophilic leukocytes.

Plasma cells were found in the cellular infiltrate throughout the entire thickness of the mucous membrane of the large intestine. They were located focal or diffusely (fig. 4). These cells were often found in small numbers in lymphoid follicles, near crypts or under crypts. It is known that basal plasmacytosis, especially when combined with crypt deformation, is a pathognomonic microscopic sign of UC [14].

T-lymphocytes were localized more often diffusely in the entire thickness of the lamina propria of the colon mucosa. Also, these cells were found between some epithelial cells and in lymphoid follicles (fig. 5).

B-lymphocytes localized focally, mainly in the entire thickness of the lamina propria of the colon mucosa around or directly in the lymphoid follicles.

Macrophages were characterized by focal or diffuse location, both in the superficial and in the deep parts of the lamina propria of the mucous membrane. Cells of the macrophage series were often located pericriptally or in places of erosive and ulcerative changes.

In the cellular infiltrate, mast cells were more often characterized by a diffuse arrangement and eosinophilic leukocytes by a focal arrangement. Infiltration by mast cells and eosinophilic leukocytes spread to deep sections or the entire thickness of the lamina propria of the mucous membrane.

Neutrophilic leukocytes in the cell infiltrate in patients of group 2 more often localized diffusely in the superficial parts of the lamina propria of the mucous membrane. With an increase in the degree of UC activity, these cells spread to the deep parts of the lamina propria, and in patients of group 4 covered its entire thickness.

Analyzing the values of central trends of the indexes of the severity of infiltration by various cells (table I) in group 2 have shown the $1^{\text {st }}$ rank place for plasma cells, the $2^{\text {nd }}$ - T-lymphocytes, the $3^{\text {rd }}$ - eosinophilic and neutrophilic leukocytes, mast cells, the $4^{\text {th }}$ - macrophages and B-lymphocytes. In group 3, the $1^{\text {st }}$ rank place was allocated for plasma cells, the $2^{\text {nd }}$ place $-\mathrm{T}$-lymphocytes, the $3^{\text {rd }}$ place - neutrophilic leukocytes, the $4^{\text {th }}$ place - eosinophilic leukocytes, mast cells, macrophages, the $5^{\text {th }}$ place $-B-l y m-$ phocytes. In group 4 , the $1^{\text {st }}$ rank place was for plasma cells, the $2^{\text {nd }}$ place - neutrophilic leukocytes, the $3^{\text {rd }}$ place - T-lymphocytes, the $4^{\text {th }}$ place - macrophages, mast cells and eosinophilic leukocytes, the $5^{\text {th }}$ place - B-lymphocytes. Thus, in groups 2-4, plasma cells, T-lymphocytes, eosinophilic and neutrophilic leukocytes prevailed in the cellular infiltrate.

In groups 2-4, in comparison with group 1, the indexes of the severity of infiltration by various cells had significantly $(p<0.05)$ larger values (table I). With an increase in UC activity, the index of the severity of infiltration by plasma cells, T-lymphocytes, macrophages and neutrophilic leukocytes increased $(\mathrm{p}<0.05)$. The index of the severity of infiltration by B-lymphocytes and eosinophilic leukocytes tended to increase $(\mathrm{p}>0.05)$ in group 3 as compared with group 2, in group 4 compared with group 3 , and in group 4 compared with group 2 it increased $(\mathrm{p}<0.05)$. The index of the severity of infiltration by mast cell tended to increase $(p>0.05)$ in group 3 compared to group 2 , increased $(\mathrm{p}<0.05)$ in group 4 compared to group 3.

Under survey microscopy of the colon mucosa in patients with IBS of group 5, compared with group 1, revealed more pronounced inflammatory cell infiltration in the superficial epithelium and lamina propria, as well as lymphoid follicles in the lamina propria (fig. 6).

In group 5, in the lamina propria of the colon mucosa in 60 cases $(73.2 \%)$ inflammatory cell infiltration was of a focal character, and in 22 cases (26.8\%) it was diffuse. Inflammatory infiltration was more often located in one third or two third thickness layers of the lamina propria of the mucous membrane (in 22 cases $(26.8 \%$ ) - in its one third of the thickness, in 59 cases $(72.0 \%)$ - in its two third, in 1 case (1.2\%) - in its entire thickness). The index of the severity of all cellular infiltration in this group had a significantly $(\mathrm{p}<0.05)$ greater value than that of group 1 (fig. 1$)$.

Cellular infiltration, revealed by observation microscopy in group 5 , was characterized by a composition similar to group 1 and was represented by plasma cells, T-lymphocytes, B-lymphocytes, macrophages, mast cells, eosinophilic and neutrophilic leukocytes.

In the lamina propria of the colon mucosa, plasma cells were often diffusely localized and occupied its upper two third of the thickness. Predominantly diffuse infiltration by T-lymphocytes, spreading to the upper two thirds of the lamina propria thickness of the mucous membrane, was determined. Focal infiltration with B-lymphocytes was found mainly in the entire thickness of the lamina propria of the colon mucosa around or directly in the lymphoid follicles. Macrophage infiltration and infiltration with eosinophilic leukocytes often had a focal character, and spread to the entire thickness of the lamina propria of the mucous membrane. Mast cells were often characterized by a diffuse arrangement in the cellular infiltrate, spreading to two thirds or the entire thickness of the lamina propria of the mucous membrane. Neutrophilic leukocytes in the cell infiltrate were found in 66 cases (80.5\%) only in the upper third of the lamina propria of the mucous membrane.

In group 5, the indexes of the severity of infiltration by plasma cells, T-lymphocytes, B-lymphocytes, macro- 
phages, mast cells, eosinophilic and neutrophilic leukocytes were significantly $(\mathrm{p}<0.05)$ higher, compared with similar indexes in group 1 (table I).

Analyzing central trends of the indexes of the severity of infiltration by various cells (table I) in group 5, plasma cells ranked the $1^{\text {st }}$ place, T-lymphocytes and mast cells - the $2^{\text {nd }}$, macrophages, eosinophilic leukocytes - the $3^{\text {rd }}$, B-lymphocytes, neutrophilic leukocytes - the $4^{\text {th }}$. Thus, in this group the predominant cells in the infiltrate were plasma cells, T-lymphocytes, mast cells, macrophages.

Most scientists also noticed inflammation signs in the lamina propria of the colon mucosa in patients with IBS [15]. The inflammatory cellular infiltration in patients with IBS, according to the literature, is characterized by a predominantly small number of macrophages, lymphocytes, monocytes, plasma and mast cells, sometimes with an admixture of eosinophilic leukocytes [16]. These changes in the cellular composition of the colon mucosa in patients with IBS lead to the increased production of proinflammatory cytokines (TNFa, IL-8, IL-6, IL-1 $\beta$, etc.). There were also significant changes in the composition of cells not only at the local (in the intestine), but also at the systemic level [17].

Comparative analysis of the data, obtained in groups 2-5, made it possible to reveal the distinctive signs of cellular infiltration in the mucous membrane of the large intestine in patients with UC of varying degrees of activity and IBS.

Firstly, in IBS compared with UC of varying degrees of activity in the mucous membrane of the colon inflammatory cell infiltration was less pronounced, more often it was localized in one third or two thirds of the lamina propria. There were fewer lymphoid follicles, cryptitis and crypt abscesses were not detected, the index of the severity of all cellular infiltration had a significantly $(\mathrm{p}<0.05)$ lower value.

Secondly, inflammatory cell infiltration in UC of varying activity degrees and IBS were characterized by the presence of plasma cells, T-lymphocytes, B-lymphocytes, macrophages, mast cells, eosinophilic and neutrophilic leukocytes. However, plasma cells, T-lymphocytes, eosinophilic and neutrophilic leukocytes predominated in the infiltrate in UC, while in IBS plasma cells, T-lymphocytes, mast cells and macrophages were predominant.

Thirdly, in IBS compared with UC of varying activity degrees the indexes of the severity of infiltration by plasma cells, T-lymphocytes, eosinophilic and neutrophilic leukocytes were significantly $(\mathrm{p}<0.05)$ lower $($ table I). The indexes of the severity of infiltration by B-lymphocytes, macrophages, mast cells in IBS were not significantly ( $p>0.05$ ) different compared with the corresponding indicators in the $1^{\text {st }}$ and $2^{\text {nd }}$ degrees of activity UC, but they had significantly $(\mathrm{p}<0.05)$ lower values compared to indicators for UC of the $3^{\text {rd }}$ degree of activity.

\section{CONCLUSIONS}

1. The mucous membrane of the large intestine in patients with ulcerative colitis of varying degrees of activity, compared with the physiological norm, has pronounced infiltration by plasma cells, T-lymphocytes, B-lymphocytes, macrophages, mast cells, eosinophilic and neutrophilic leukocytes in the superficial parts of the epithelium, crypts, lamina propria. There is also an increase in the number and size of lymphoid follicles in the lamina propria. Predominant cellular elements in the infiltrate are plasma cells, T-lymphocytes, eosinophilic and neutrophilic leukocytes.

2. The growth of ulcerative colitis activity leads to an increase the inflammatory cell infiltration in the mucous membrane of the colon, as evidenced an increase the density of cellular infiltrate; the severity of inflammatory changes in crypts and an increase in the number of crypt abscesses; a decrease the number of cases with focal infiltration in the lamina propria and an increase the number of cases with diffuse infiltration; the spread of inflammatory cell infiltration from the superficial parts of the lamina propria to its deep parts with the subsequent involvement of its entire thickness; an increase the central trends of the indexes of the severity of all cellular infiltration, infiltration by plasma cells, T-lymphocytes, macrophages, neutrophilic leukocytes.

3. The mucous membrane of the large intestine in patients with irritable bowel syndrome has moderately pronounced cellular infiltration in the superficial epithelium and lamina propria, in comparison with the physiological norm. The number and size of lymphoid follicles increase. Inflammatory cell infiltration often spreads to the upper one third or two thirds of the thickness of the lamina propria, characterized by the presence of plasma cells, T-lymphocytes, B-lymphocytes, macrophages, mast cells, eosinophilic and neutrophilic leukocytes. In this case, plasma cells, T-lymphocytes, mast cells and macrophages dominate. The indexes of the severity of all cellular infiltration, as well as infiltration by plasma cells, T-lymphocytes, B-lymphocytes, macrophages, mast cells, eosinophilic and neutrophilic leukocytes, increases in the mucous membrane of the large intestine in irritable bowel syndrome in comparison with the norm.

4. In the mucous membrane of the large intestine in irritable bowel syndrome compared with ulcerative colitis of varying degrees of activity inflammatory cell infiltration is less pronounced. It often extends to one third or two thirds of the thickness of the lamina propria. There are fewer lymphoid follicles, cryptitis and crypt abscesses are not determined. The indexes of the severity of all cellular infiltration, as well as infiltration by plasma cells, T-lymphocytes, eosinophilic and neutrophilic leukocytes are lower.

5. The revealed features of cellular infiltration in the mucous membrane of the large intestine make it possible to improve morphological diagnostics, including differential, of ulcerative colitis of varying degrees of activity and irritable bowel syndrome.

\section{REFERENCES}

1. Kushnir IE. Terapevticheskie strategii lechenija jazvennogo kolita: realii i perspektivy. Therapeutic treatment strategies of ulcerative colitis: realities and future. Modern gastroenterology. 2016; 4(90):108-115. (Ru) 
2. Stepanov YuM, Psarova IV. Kliniko-endoskopichni paraleli pry nespecyfichnomu vyrazkovomu koliti. Clinical and endoscopic parallels in ulcerative colitis. Gastroenterologì. 2019;53(3):182-187. (Ua)

3. Schmulson MJ, Drossman DA. What is new in Rome IV. Journal of Neurogastroenterology and Motility. 2017;23(2):151-163.

4. AkhmedovVA, Sargsyan AK, Gaus OV. Perspektivy ispolzovanija biomarkerov v diagnostike sindroma razdrazhennogo kishechnika. Prospects for the use of biomarkers in the diagnosis of irritable bowel syndrome. Experimental and Clinical Gastroenterology. 2020;175(3):94-101. (Ru)

5. Sheptulin AA, Vinogradskaya KE.Vospalitelnye zabolevanija kishechnikai sindrom razdrazhennogo kishechnika: sochetanie dvuh nozologicheskih form ili raznye varianty odnogo zabolevanija? Inflammatory bowel diseases and irritable bowel syndrome: overlap of two nosological forms or two variants of the same disease? Russian Journal of Gastroenterology, Hepatology, Coloproctology. 2019;29(5):43-48. (Ru)

6. Klyaritskaya IL, Moshko YA, Viltsanyuk IA. Novye podhody k ocenke biopsii pri vospalitelnyh zabolevanijah kishechnika. New approaches to the assessment of biopsies in inflammatory bowel disease. Crimean Journal of Internal Diseases. 2014;2:38-60. (Ru)

7. Aruin LI, Kapuller LL, IsakovVA. Morfologicheskaja diagnostika boleznej zheludka i kishechnika. Morphological diagnosis of diseases of the stomach and intestines. M.: Triada-X, 1998. 496 p. (Ru)

8. Kobzar Al. Prikladnaja matematicheskaja statistika. Applied mathematical statistics. M.: Fizmatlit, 2012. 816 p. (Ru)

9. Feakins RM. Inflammatory bowel disease biopsies: updated British Society of Gastroenterology reporting guidelines. Journal of Clinical Pathology. 2013; 0:1-22. doi:10.1136/jclinpath-2013-201885.

10. BelousovYuV, SadchikovVD, Belousova OYu, Dolgaya OV. Klassifikacionnye morfologicheskie harakteristiki hronicheskogo nespecificheskogo nejazvennogo kolita u detej. Classification morphological characteristics of chronic nonspecific nonulcerative colitis in children. International medical journal. 2004;2:29-31. (Ru)

11. Nikipelova EA, Kit OI, Shaposhnikov AV, Zlatnik EY, Novikova IA. Kolokancerogenez: onkoimmunologija lokalnyh izmenenij. Colocarcinogenesis: oncoimmunology of local changes. Malignant tumours. 2016; 4(1):81-86. (Ru)

12. Sorokina I, Myroshnychenko M, Sherstiuk S, Zubova Y, Nakonecha S, Panov $S$. The morphological picture of local immune responses in the kidneys, ureters and bladder of the foetuses and newborns, who developed in conditions of maternal preeclampsia. Georgian medical news. 2018;2(275):123-132.

13. Snisarevskyi PP, Dyadyk 00, Dorofeyev AE, Snisarevska PP. Rol morfologichnogo doslidzhennja $v$ diagnostyci nespecyfichnogo vyrazkovogo kolitu. The significance of morphological research in the diagnosis of ulcerative colitis. Art of medicine. 2018;3(7):127-132. (Ua)
14. Pai RK, Jairath V, Casteele NV, Rieder F, Parker CE, Lauwers GY. The emerging role of histologic disease activity assessment in ulcerative colitis. Gastrointestinal endoscopy. 2018;88(6):887-898.

15. Maev IV, Bordin DS, Eremina EU, IIchishina TA, Kaibysheva V0, Osipenko MF, Okhlobystin OZ, Simanenko VI, Khalif IL, Cheremushkin SV, Sabelnikova EA. Sindrom razdrazhennogo kishechnika. Sovremennye aspekty jepidemiologii, patogeneza i lechenija (obzor). Irritable bowel syndrome. Modern aspects of epidemiology, pathogenesis and treatment (a review). Experimental and Clinical Gastroenterology. 2018;158(10): 68-73. (Ru)

16. Tikhonova TA, Kozlova IV. Sindrom razdrazhennogo kishechnika: jepidemiologicheskie i patogeneticheskie aspekty (obzor). Irritable bowel syndrome: epidemiological and pathogenetic aspects (review). Saratov Journal of Medical Scientific Research. 2018;14(1):53-60. (Ru)

17. Kudryavtsev IV, Ermolenko El, Solovieva OV, Serebriakova MK, Shumikhina IA, Suvorov AN. Subpopuljacionnyj sostav T-limfocitov pri sindrome razdrazhennogo kishechnika. Subpopulation composition of T-lymphocytes in patients with irritatable intestinal syndrome. Experimental and Clinical Gastroenterology. 2019;165(5): 22-28. (Ru)

\section{ORCID and contributionship:}

Olena O. Dyadyk: 0000-0002-9912-4286 A,B,C,E

Pavlo P. Snisarevskyi: 0000-0002-4454-3678 A,B,D,E,F

Tetiana P. Snisarevska: 0000-0003-3931-2848 C,F

\section{Conflict of interest:}

The Authors declare no conflict of interest.

\section{CORRESPONDING AUTHOR Pavlo P. Snisarevskyi}

Shupyk National Medical Academy of Postgraduate Education 9 Dorohozhytska str. 04112, Kyiv, Ukraine

e-mail: patholognew@ukr.net

Received: 03.08 .2020

Accepted: 22.12 .2020

A - Work concept and design, B - Data collection and analysis, C - Responsibility for statistical analysis, D-Writing the article, E-Critical review, $\mathbf{F}$ - Final approval of the article 